\title{
Brexit uncertainty is unsettling EU doctors working in UK
}

\author{
The question is not just whether they can work in the UK but whether they will want to, finds Bryan \\ Christie
}

\section{Bryan Christie}

\section{Edinburgh}

Thomas Robertson worries about his future. The consultant anaesthetist at Ninewells Hospital in Dundee is an EU migrant. He trained in Germany, worked in Spain, and has now made his home in Scotland. He believes he will be able to stay in the UK after Brexit, but the process has been so unsettling that he and thousands of other doctors from other EU countries are facing a bigger question: will they want to?

Doctors who qualified in other European countries made up 9\% of those on the UK medical register in 2017, GMC data show. ${ }^{1}$

A BMA survey of 1720 doctors from other European Economic Area (EEA) countries working in the UK carried out at the end of last year found that almost half (45\%) were considering leaving as a result of the referendum vote. ${ }^{2}$ At the same time, uncertainty exists about the rights of more EU medical professionals to come to work in the UK after Brexit. These are doctors that the NHS can ill afford to lose, as this would put services under further pressure, given current caps on numbers of visas issued to doctors from non-EEA countries. ${ }^{3}$

These EU doctors are ones that the NHS can ill afford to lose, given caps on numbers of visas issued to doctors from non-EEA countries

Robertson appreciates the support offered by the Scottish government, which has said that it values the contribution of EU migrant workers in the health service, but he says the real decisions are being made elsewhere. "The apparent inability of the British government to develop a feasible proposal for Brexit and the future of the medical profession is worrying," he said. "I think European doctors in Scotland and the [rest of the] UK are aware that we are in a privileged position compared with most migrants and - even in a worst case scenario- that we are very likely to be able to manage. For many the question is, rather, how much uncertainty and hardship can we take until we decide we do not want to stay in the UK anymore?"

\section{Keeping Europe Healthy}

The importance of maintaining a free flow of medical professionals across borders was highlighted at a meeting at the European Parliament on 23 May, attended by MEPs, representatives of medical organisations, and policy officials.
"Keeping Europe Healthy: Brexit and the European Medical Profession" called for greater priority to be given to health issues in the detailed negotiations between the EU and the UK over the final Brexit settlement.

The BMA was represented by its Scottish chair, Peter Bennie. He described the meeting as very useful and said that it made clear the severe consequences that would arise if free movement of doctors across the EU were ended or curtailed. However, solutions were worryingly short, he said.

"The benefits of allowing doctors to practise freely across the EU are manifold," Bennie said. "Not least among them is the substantial contribution doctors from across Europe make to delivering care in our NHS. At a time when our workforce is already stretched to its limits, it is unthinkable that we could simply stand by and lose this important supply line of doctors for our hospitals and communities.

"But it is not just a numbers game. The free exchange of ideas and experiences that doctors pick up from working in different health systems, and that European doctors bring, benefits them as professionals, their colleagues, and the patients they care for."

\section{Exodus}

Figures from the General Medical Council show that there are 31503 doctors registered to practise in the UK who qualified in other EEA countries. Bennie said that if Brexit were handled poorly there would be the risk of an exodus of these doctors from the NHS and of far fewer being recruited. This would be damaging for the EU as well as the UK, he said, and pressure needed to be applied on both sides of the negotiations to get the best deal possible.

Part of this will include the mutual recognition of medical qualifications across the EU to ensure that doctors do not face geographical disadvantage. Students from other EU countries who qualify in the UK have no certainty at the moment as to whether their qualification will be valid in Europe after Brexit. "Since 2010, more than 200 students from the EU have graduated from Scottish medical schools. We want these future doctors to stay in Scotland out of choice-because this is a great 
place to live and work-yet we risk losing them before they even qualify due to this ongoing uncertainty," said Bennie.

Students from other EU countries who qualify in the UK have no certainty at the moment as to whether their qualification will be valid in Europe after Brexit

Meanwhile, doctors like Thomas Robertson watch on from the sidelines. While Brexit negotiations continue to be dominated by talk of trade, customs deals, and border arrangements, doctors wait in hope that the negotiators will get round to considering solutions that will recognise the importance of the free flow of medical staff.

1 Moberly T. EU doctors make up 9\% of the UK medical workforce. BMJ 2018:360:k641. 2 lacobucci G. Half of doctors from other EEA countries working in UK may leave, poll shows. BMJ 2017;359:j5273. 10.1136/bmj.j5273 29138134

3 Limb M. Capping entry visas is creating "massive longstanding" problems, says head of NHS trust. BMJ 2018;361:k2224. 10.1136/bmj.k2224 29776918

Published by the BMJ Publishing Group Limited. For permission to use (where not already granted under a licence) please go to http://group.bmj.com/group/rights-licensing/ permissions 